\title{
The Formulation Of Management Standard For Karawang Kota Santri Program
}

\author{
Amirudin $^{1}$, Umar Mukhtar $^{2}$, Iqbal Amar Muzaki ${ }^{3}$ \\ \{amirudin@staff.unsika.ac.id ${ }^{1}$, umarmukhtar2105@gmail.com ${ }^{2}$, bayonline9013@gmail.com ${ }^{3}$ \} \\ Singaperbangsa Karawang University, Indonesia ${ }^{1,2,3}$
}

\begin{abstract}
Karawang City of Santri is a manifestation of Islamic education that aims to form human beings who are then expected to provide a social effect in building a civil society. Thus, if the Santri City projection in Karawang goes well, then human quality will be able to be improved simultaneously. In terms of developing the potential of Islamic education, Karawang Kota Santri has an ideal goal, which is to build a prosperous, safe, and prosperous society through planting and practicing Islamic values in social life, so that if realized it will be able to provide positive implication for the community. But to realize it, all the supporting devices needed to support the success of the program are needed. The device consists of a governance system that must be made accommodatively along with the driving device, that is, the capacity in implementing the system that has been created. The system is then used as a standard in the management of Karawang Kota Santri starting from planning, implementation to evaluation.
\end{abstract}

Keywords: Standards, Management, City of Santri

\section{Introduction}

Human development is the core of the national development of every nation and state. Because in a nation, aspects of human resources are the most important element in building an ideal civilization. A developed nation will be directly proportional to the quality of its capable human, and vice versa, an underdeveloped nation is the implication of its lowquality human condition. So then humans become a determining factor in assessing the level of progress of a country with the calculation of the Human Development Index (HDI).

Indonesia as a developing country has a record that is not so satisfying in terms of HDI. M. Zaid Wahyudi [1] said that the Human Development Index (HDI) of Indonesia was ranked 110 of 188 countries and below neighboring countries like Singapore, Malaysia and Thailand. Meanwhile, Karawang as one of the regions that is continuing to pursue regional development, has an IPM report card that is not so proud. Fakta Karawang [2] reported that the Human Development Index (HDI) Karawang reached 67.60 ranks 16 out of 27 districts/cities in West Java and still below the regional neighbors, Purwakarta. This certainly is a whip for all elements of the Karawang community, especially the Regional Government to continue to improve the quality of life for the achievement of the ideal civilization as aspired by every human being.

In the context of human development, the most fundamental of various aspects of human development is the education sector. Why is that? Because this sector will have a major effect on changing people's lives. A good education will produce a good civilization. There is no 
country in this world that wants progress without regard to its educational aspects which must be optimized to uplift the nation's dignity.

In practice, religious education should have a central position in community empowerment and the environment. This has implications for the beliefs held by the community so that it becomes a doctrination to be able to carry out life according to God's guidance and become a culture that is rooted, so that religion truly becomes a role model and guide in social life. Then it is the responsibility of every element of society to be able to carry out religious education, with the hope of the formation of social life that upholds the values of divinity and social culture. So that civil society will be formed from an ideal social life and in accordance with Islamic sharia values.

Some time ago, the Karawang Ministry of Religion had launched the Karawang into the City of Santri. This discourse seems to give a breath of fresh air for the implementation of religious education in Karawang, especially among Pondok Pesantrens, which in the era of industrialization like today seems to decrease public interest in studying religion. This condition is reinforced by the tendency of people who prefer to study at public schools compared to Islamic educational institutions with various stigmas that arise, both from students or their parents. As a result, Pondok Pesantrens and madrassas, which are Islamicstyle educational institutions, are "not in demand".

Karawang City Santri is a manifestation of Islamic education that aims to form human beings who are then expected to provide a social effect in building a civilized civil society. So by rolling out the Karawang City of Santri discourse it should be able to boost the quality of religious education and invite all elements of society to be able to optimize religious education so that Karawang is able to become an upright pillar of Indonesia as a baldatun thayyibatun wa rabbun ghafuur. It's not too much if we hope so. Because the concept is a picture of a very ideal civilization, namely a good national life and be in the pleasure of Allah swt.

The problem is that it has been running for several years since the discourse rolled out, there has not been any satisfactory progress to realize Karawang Kota Santri. For this reason, it is necessary to formulate standards for the realization of the program so that there are clear benchmarks. In line with what was expressed by Jo Santoso [3], that if seen from its size, function, history and cultural background, each city has its own characteristics. So if we want to maintain the characteristics of a city, it is clear that a standard of evaluation that includes the existence of local characteristics is needed as one of the important criteria. Therefore, an in-depth study is needed to determine which indicators best represent the living conditions of people in a city.

\section{Literature Review}

When viewed from the phrase structure, the City of Santri consists of two words, namely city and santri. In terms of language, the city is a residential area and buildings which are a unity of residence [4]. In terms of, Tarigan [5] explains that the city can be defined as a concentration of people and activities. What is meant by a city in this term is not a city in the sense of division of territory based on the level of progress of an area such as urban and rural, but as a place of concentration that is the center of activity of the local population so that it becomes the character and even the culture of the community concerned.

Then the word santri comes from the Indian language, namely shastri which means literacy or sacred books or religious books. People called santri are people who have learned books written in Arabic and become aware of religion. Because studying religion, students' understanding of religion is getting deeper. So santri means a person whose religion of Islam 
is profound. While the word sastri comes from the Tamil language which means the teacher of the Quran also has closeness with the word santri. The word sastri is influenced by the word shastri from India. The word shastri, which means literacy or religious books, is experiencing a development in the meaning of being a Quran teacher. Santri is a person who has a deep religious knowledge and because of his extensive knowledge, to some places where people learn or become teachers of the Quran [6].

From the above definitions, it can be concluded that the City of Santri is an area where the community is concentrated in religious activities, in this case there are many people who study religious knowledge, especially in Pondok Pesantrens in the region. This understanding also refers to some areas that are already known as the City of Santri or santri areas. For example, the writer took from the famous City of Tasikmalaya as the City of Santri because there are many Pondok Pesantrens and other Islamic educational institutions that stand in the city.

An area known as the City of Santri is inseparable from the lives of students who are actively studying religious knowledge and carrying out Islamic teachings. Then the atmosphere of the santri's life will not be far from the place where undertakes various activities related to the status of the santri bears, namely Pondok Pesantren. So that in the context of the City of Santri, it can be understood as an area in which stands many Pondok Pesantrens which become Islamic educational institutions along with elements that complement their existence. Therefore to know the characteristics of the City of Santri need to understand the ins and outs of Pondok Pesantrens and their lives.

Etymologically, the Pondok Pesantren consists of two words: pondok and pesantren. The word pondok comes from the word funduq (Arabic) which means hotel or hostel. While in the Bahasa has many meanings, one of which is a madrasa where learning Islam. Similar institutions, in the end, better known as pondok pesantren. In West Sumatra known as surau, while in Aceh known as rangkang [7].

Then word 'pesantren' comes from the santri, that began with pe- on the front and the suffix -an means abode of the students [8]. So it can be concluded that the Pondok Pesantren is a house that is used as a place for students in studying religious knowledge to their teachers (scholars or clerics).

Pondok Pesantrens as classical/traditional Islamic education institutions in Indonesia do have a very important role for the community. During the colonial period, santri from various pesantren contributed positively in taking the fight to seize independence from the invaders. The heroic struggle proves that Pondok Pesantrens are not only a place to study religion, but also as a center of people's struggle in fighting for a better community life. In its role as a center for Islamic education, pesantren also functions as a moral reference for the community, where ulama or kyai figures always become role models and their words become fatwas in taking a stand.

Horikoshi in Suparta and Haedari [9] said that from time to time the function of pesantren runs dynamically, changes and develops following the social dynamics of the global community. Imagine, at first this traditional institution developed a function as a social institution and religious broadcasting. More than that, Azyumardi Azra in Nata [10] offers three functions of pesantren, namely: (1) transmission and transfer of Islamic sciences, (2) maintenance of Islamic traditions, and (3) reproduction of scholars.

Then in the development of pesantren, there are five basic elements that are characteristic of each pesantren tradition that grows in various regions, namely [11]: (1) Cottage, (2) Mosque (3) Teaching classical Islamic books, (4) Religious person, students of Islam, (5) Kyai. 
With a variety of distinctive characteristics inherent in the Santri City brand seen as able to reinforce the position of Islamic education as the main capital in human development efforts. Especially in this increasingly sophisticated era, the turmoil of thinking is increasingly uncertain given the development of the world referred to by Giddens as runaway world, as if running helter-skelter [12]. In such a situation, the position of Islamic education is needed as an effort to build a civilization that is tawasuth (moderate) and tawazun (balanced).

Abdurrahman an-Nahlawi [13] said that Islamic education with all its characteristics is a remedy for various diseases that plague the community, because Islam has offered a complete education system from the source to the principles, methods and paths. Therefore, the optimization of Islamic education is a necessity in human development with its nature that never goes out of date even though the times have undergone many transformations.

The urgency of Islamic education cannot be separated from ta'rif and also the concepts attached to it. There are several terms commonly used in defining education, namely tarbiyah, ta'lim and ta'dib. Abdurrahman an-Nahlawi [14] explains the term al-tarbiyah (التربية) is rooted in three words, first, comes from the word rabba - yarbuu (ربـ يربو) which means growing and growing. Second, rabiya - yarbaa (ربي- يربي) with wazan (form) khafiya-yakhfa ( - خفي (رب) (يخفي). Third, rabba - yarubbu (رب - يرب) which means to improve, master the affairs, guide, maintain and maintain. Of the various scopes related to Islamic education, the most popular used to interpret Islamic education is tarbiyah. This is because the scope contained in the meaning of tarbiyah is more comprehensive, covering all educational activities so that it is considered representative in interpreting Islamic education, and interpreted as an effort made systematically by educators in developing one's potential by internalizing the values of Islamic education as provision in wading life in the world and the hereafter. Islamic education has a central role for a human being in his context as a servant of God, because with Islamic education he will find a way as a means of worship that is an obligation for God's creatures, as he said:

"And I did not create jinn and men but that they worship me." (Surah adz-Dzaariyaat: 56)

Hasan Langgulung [15] says that the objectives to be achieved by Islamic education can be summarized in two main objectives: the formation of a pious and faithful person in Allah and His religion, and the formation of a pious society that follows the instructions of the Islamic religion in all its affairs. The point is to realize pious people, because pious individuals will form pious societies in their community. So in Hasan Langgulung's opinion, the formation of righteous people is at the beginning, and then the righteous community. Then what is meant by righteous human beings is humans who are nearing perfection. What is meant by the formation of a pious person is the development of people who worship and fear Allah, human beings who are full of faith, relate to God by caring for and facing Him in all their deeds done and all their actions, all thoughts that are etched in their hearts and all feelings ticking in his heart. He is a human who follows in the footsteps of the Apostle in his thoughts and deeds.

\section{Research Methods}

In this study, the authors used a qualitative approach with descriptive methods to understand the phenomena about what happened in the field. In the data collection technique this research was carried out by using observation techniques (pasrticipation-observation), indepth interviews, and documentation.

Interviews were conducted by the author to obtain data from government agencies such as the Head of the Karawang Regency Ministry of Religion, Deputy Regent, Karawang DPRD Members, community leaders, religious leaders and social institutions. Meanwhile, to collect 
data in this study, the researchers made use of various data and theories obtained from books, the internet, and newspapers, and other non-human sources of information that supported the research. The collected data were analyzed using interpretive descriptive techniques. The process of data analysis includes the presentation of data, data reduction, drawing conclusions and interpretations. By using interpretive analysis, it also accommodates concepts that have been used as theoretical references. This research method is applied, so that the results of this study are not only descriptive, but also part of theoretical criticism and building new theories.

\section{Research Results and Discussion}

\section{a. The Karawang City Concept of Santri}

Basically Karawang Kota Santri is a discourse issued by the Karawang Regency Ministry of Religion to improve the quality of society by instilling Islamic values in daily life. This was explained by H. Sopian (Head of the Office of the Ministry of Religion Karawang). According to him, by applying and instilling the values of Islamic teachings, a prosperous, safe, comfortable, orderly, harmonious and beautiful society will form as the motto or motto of West Java, namely Gemah Ripah Repeh Rapih.

If quoting on the official website of the West Java Provincial Government (www.jabarprov.go.id), the motto in question is a slogan that comes from Sundanese and is a compound word that means:

- Gemah-ripah: fertile prosperous, sufficient clothing and food.

- Repeh-rapih: harmonious and peaceful or safe

So that when combined will have the meaning of rich and fertile prosperous and inhabited by many residents who live in harmony and peace.

The concept offered by the Karawang Regency Ministry of Religion is actually a form of practice of the values of Islamic civilization contained in the Quran, Allah swt said:

"And when Ibrahim said: My Lord, make it a secure town and provide its people with fruits, such of them as believe in Allah and the last day. He said: And whoever disbelieves, I will grant him enjoyment for a short while, then I will drive him to the chastisement of the fire; and it is an evil destination." (QS al-Baqarah: 126 )

And also in another verse Allah says with almost the same purpose:

"And if the people of the towns had believed and guarded (against evil) We would certainly have opened up for them blessings from the heaven and the earth ..." (QS al-A'raaf: 96 )

In fundamental understanding, the City of Santri is one of the programs that should be a concern in Karawang, so that if it is realized it will involve many parties, including the legislative element. H. Endang Sodikin (Deputy Chairperson of Commission D of the Karawang DPRD) defines the City of Santri as a future miniature of Karawang. The connection with the City of Santri, it is not enough just with discourse, it needs support from the local government and DPRD and the community, and even then naturally it must be supported by areas where there are resources. Karawang itself has the potential to be associated with heritage (historical heritage, traditions and values), with regard to Buddhism, Hinduism, as well as the Islamic site of Sheikh Quro which is older than the saints. Surely this is a natural potential, just how the local government designs so that the Santri City pattern is integrated with the destination and with the city center, pesantren-based sub-districts, so that this planning requires a relatively short period of time, there needs to be a clear political will from the government and careful planning. In accordance with the mandate of the law, the 
DPRD together with the Regional Government is an element of government administration. Especially in Karawang itself there is some potential for the development of the religious sector, there is the tomb of Sheikh Quro, and there is also the potential associated with pesantren such as in Rawamerta, even when seen again, in every district in Karawang it has a pesantren. So, Karawang Kota Santri should not just be a jargon.

But H. Ahmad Zamakhsyari, Deputy Regent of Karawang stated that the naming of the City of Santri was inappropriate, because it would lead to different interpretations for those who heard it. In other words, Karawang Kota Santri means the entire region has a culture of santri and pesantren. This is considered difficult, because Karawang is an ethnic and cultural crossing area, where there is Sian Djin Ku Poh (the oldest Buddhist temple in Karawang), Soul Temple, several sites in Kutatarison and Mount Sanggabuana. So it can't be forced upon Karawang to become the City of Santri. For this reason, it should be noted also what parameters and definitions of the City of Santri are. The City of Santri is synonymous with the majority of Pondok Pesantrens, while in Karawang it is uneven. So it is more appropriate to be called Kampung Santri in the majority zone of Pondok Pesantrens, not for the entire Karawang region.

Apart from differences of opinion regarding the naming of the program, the most important thing is how this program can be realized properly so that it has a positive impact on people's lives. In fact, after the appointment of Rawamerta as the Santri City pilot project, it became an affirmation that the region did have a strong culture of santri and pesantren. KH. Bubun Bunyamin Bushaeri said that the community responded very well by participating in Islamic education activities both in Pondok Pesantrens, majlis ta'lim and in schools. To invite public response is actually not too difficult, because basically Islamic culture has been built in the midst of society. The culture can be seen from routine activities that are often carried out and are inherent in the daily life of the community, such as the Quran, recitation, tahlilan, reading ratib, and others. He further said that there were some changes in society after the realization of the City of Santri. Previously, every big day was often done entertainment programs, at this time such activities do not exist, replaced with Islamic activities, such as pilgrimage, recitation, and others.

Because of the diversity of cultures in Karawang, stakeholders who have the authority to initiate the City of Santri must design it in such a way that the City of Santri can be in line with development prospects, both human resources and infrastructure. H. Endang Sodikin said that the basic concept of the City of Santri emphasized more on the inculcation of Islamic values and gave rise to Islamic symbols as well as thick culture of santri and religion. In addition, the Karawang City Karawang must be able to introduce more intensively towards religious tourism destinations such as the Sheikh Quro site. In this case certainly there is a need for good cooperation from all elements, starting from the local government, DPRD, religious leaders, community leaders, even the community itself. Thus, in the process, the realization of program Pupils City This needs no persuasion is the responsibility together. Sociologically the target will continue to increase in 10 to 15 years.

Based on documentation studies it is known that the potential of Karawang in terms of Islamic educational institutions is enormous. This potential can be a good capital to be able to realize Karawang as a city of Santri.

Table 1. Data of Islamic Education Institutions in Karawang Even Semester 2018-2019

\begin{tabular}{|c|l|c|c|}
\hline No. & Islamic Education Institute & Amount & Amount of Santri \\
\hline 1 & Pondok Pesantren & 509 & 50,210 \\
\hline 2 & DTA & 1015 & 93,923 \\
\hline
\end{tabular}




\begin{tabular}{|c|l|c|c|}
\hline 3 & DTW & 5 & 135 \\
\hline 4 & LPQ & 959 & 30,547 \\
\hline
\end{tabular}

If drawn back to the goals of the City of Santri in line with the objectives of Islamic education, KH. Bubun Bunyamin Bushaeri (Chairman of Al-Banin Pondok Pesantren Nihayatul Amal Rawamerta) said that along with the preparation of Karawang for the City of Santri, Islamic da'wah should be carried out more intensively. Pondok Pesantrens have a responsibility in conveying Islamic sciences. The pesantren became the center of Islamic civilization, and made Islamic values a culture in society.

In its application, the Santri City program is one of the strategies to instill the values of Islamic education more intensively in the daily lives of students even in the community, where this policy is implemented. H. Endang Sodikin said that Islamic values would be maintained if the community applied the values themselves, so that with the City of Santri it was hoped that they could maintain Islamic values in the community. The City of Santri will also be a filter for the community towards western culture, because in an era like today modernization can no longer be dammed. The principle is to maintain a good old culture and take a good new culture. Then it must be emphasized the realization of Islamic values that are relevant to time and conditions like anything.

This principle has indeed long been held by most of the ulama in Karawang even in Indonesia. Especially if you look at the situation as it is today, where freedom of association and interaction with other nations and countries is no longer possible. So if you do not have a strong foundation, the local wisdom of the people who have become a cultural heritage will be eroded by time. A rule says:

"Maintain a good old legacy and take on new, better cases."

By implementing the values of Islamic education in the community means an effort to create a civilization that is ready for the challenges of the times but still adheres to the teachings of Islam. This can be seen from the meaning of Islam itself which is the way to a better human life. Sofyan Sauri [16] says that the meaning of Islam in Arabic comes from the word aslama which means:

a.Islam means obeying/submitting to Allah Almighty.

b.Islam means peace and compassion.

c.Islam means survivors, meaning that Islam is a clue to get salvation of life both in the world and in the hereafter.

\section{a. Steps in Realizing the Santri City Karawang Program}

In its realization, the Karawang City of Santri program will be applied zoningly, in this case the Karawang Regency Ministry of Religion has appointed Rawamerta as the Santri City pilot project. The appointment of Rawamerta as a Santri City pilot project is based on observations, that Rawamerta has the potential to be associated with excellent santri compared to other districts. Then the determination was socialized through a meeting between representatives of the Karawang DPRD Commission D, Rawamerta Sub-District Head, KUA Rawamerta Head, Village Head, MUI Rawamerta District and the community on January 12, 2016 [17].

The effort to make Karawang towards Santri City would not require a short time. This is because the necessity of improvement from various sectors related to the discourse. But since a few times, the Regional Government together with the Karawang Regency Ministry of Religion has made many innovations especially in the religious field that can support the 
realization of Karawang towards the City of Santri. Among these innovations was the enactment of Regional Regulation No. 7 of 2011 concerning Compulsory Education for Diniyah Takmiliyah Awaliyyah (DTA) and al-Qur'an Education Park (TPQ) in Karawang Regency which was later strengthened by Karawang Regent Regulation No. 9 of 2013.

In addition, since 2016 the Government has implemented the Karawang Mengaji program, which is carried out in rotation in each sub-district in Karawang every month. From the observations that have been made it can be seen that the community is accustomed to holding an Islamic holiday commemorating such as the celebration of the Islamic new year with torch relay, tabligh akbar events, compensation and mass circumcisions. When the momentum of the birthday of the Prophet Muhammad SAW arrived, the crowd carried out the commemoration of the Prophet's birthday with a variety of activities. Likewise during other holidays such as the commemoration of the events of the isra mi'raj, nuzulul Qur'an and the feast of Eid al-Fitr and Eid al-Adha.

These various programs must certainly be used as the right momentum to continue to increase awareness of the importance of religious education and at the same time to socialize the objectives of the Karawang City of Santri so that it can be known by the wider community. Thus it is expected that policy makers can synergize well with one another, including with the layers of society, especially from the Pondok Pesantrens as implementers of religious education with a characteristic style as an Islamic educational institution.

In realizing the Karawang City Santri program requires careful planning and carried out in stages. H. Endang Sodikin said, with step by step, Rawamerta will serve as a pilot project to have a religious nuance each gate entrance gate to Rawamerta across borders. Then lafadzasmaul husna will also be installed in public spaces. After that the Regional Government must also make policies that encourage the improvement of the quality of madrassas and Pondok Pesantrens. Santri City Karawang will be implemented in stages, starting at Rawamerta. In the future, it might also be applied in other regions, so that later it will become a special treasure in Karawang. Maybe later Karawang will be made into zones, such as the granary zone, the industrial zone, the cultural zone, including the santri zone, so it becomes a color that does not touch each other.

In conducting program planning, an in-depth analysis needs to be done, because Karawang Kota Santri is a long-term program that can have impacts for years to come. H. Endang Sodikin explained in detail his various considerations regarding the City of Santri with a SWOT analysis including:

1) Strengths:

- Karawang Regency is a base of Pondok Pesantren which gives birth to many qualified people

- Every district in Karawang has a Pondok Pesantren

- Madrasah potential, especially in the rural environment, is still in high demand by the community

2) Weaknesses:

- Many pesantren do not meet administrative requirements

- Karawang is still thick with Jaipong dance, especially during the festive season, and also cultures that are not in accordance with Islamic values, even though it is a local wisdom

- Karawang is in the transition period from agrarian to industrialization which will bring expatriates from various countries 


\section{3) Opportunities:}

Can be developed in accordance with the pace of development of Karawang how to encourage it to be a solution for the existence of madrasas

4) Threats (threats):

With the transition of Karawang community culture, so it is feared that religious culture will be eroded

From this analysis will certainly result in careful planning the results of inter-line coordination involved in the realization of Karawang Kota Santri. But the thing that is no less important is the alignment of the vision first, so that it will produce unidirectional goals and benefits that can be felt by the community. After the vision is fixed, according to KH. M. Tholhah Hasan said in the epilogue the Ethics of the Santri Study; The New Face of Islamic Education [18] there are two important things that must be arranged. First, the problem of quality in educational human resources. At present, the teacher is a profession, in the sense of a task that demands certain expertise, and has special ethics for the position, as well as standard services in the community that needs it, with certain rewards a profession is an activity of someone with a standard of expertise to live his life (earning living). Islamic education institutions need to improve the quality of teachers or religious teachers. Second, the problem of education management. In order to improve the management of Islamic education, efforts must be made so that the application of its management can act as a process of organizational empowerment (the process of empowering the organization) and the formation of Islamic environmental culture (Islamic milieu).

\section{b. Formulation of Management Standards for Karawang City of Santri}

In a program or work plan, a standard has a very important position. This is based on its function as a basis and benchmarks in the realization of the program or work plan. In addition, the standard also serves to direct the running of a program so that it can be realized in a consistent, effective, efficient, systematic and well-managed manner so that the aims and objectives of the program can be achieved and on target. There is no program that runs successfully without a measure of success itself, so the standard then plays a role as a measuring tool as well as a basis for controlling the running of the program.

In conducting this research, the author tries to dig up data from various sources, especially from the Local Government so that it can be taken as a basis for the preparation of a standard in an effort to realize Karawang towards Santri City. In this case the Karawang Regency Ministry of Religion as the originator of the Karawang City of Santri plays a large role in the leading sector of the Karawang community's religious life. Then the executive and legislative sectors (DPRD) have a role in drafting regulations and steps that need to be taken.

So based on previous presentations, several important points can be drawn regarding the need for standards in the realization of Karawang Kota Santri, including:

1) Efforts to optimize the implementation of religious education in order to be realized comprehensively.

2) The purpose of religious education which is integrated with the community is organized by formal, non-formal and informal institutions.

3) Attract the role of various parties to improve the quality of the Karawang community through the optimization of education.

4) Increasing the role of Pondok Pesantrens and other Islamic educational institutions to foster and facilitate the community in facing the flow of change both globally and regionally. 
5) Maximizing the potential of the Karawang Regency in the religious sector which has developed into a culture among the people.

6) Give encouragement to stakeholders in Karawang regency related to the realization of Karawang Kota Santri.

7) Reinforce Karawang's identity as an area of religious character.

8) Encouraging the reconstruction of the history of Karawang as one of the gates of the spread of Islam on the island of Java.

In an effort to realize the Karawang City of Santri, the author has not found a standard that is standard as a guide for the implementation of the program. For this reason, an implementation and management standard must be developed that can be used as procedural and technical guidelines formulated from various sources. The writer who has explored various data and information related to Karawang Kota Santri formulates the implementation standards as follows:

a. Planning

In this planning process, it is necessary to formulate carefully what needs to be prepared in the framework of Karawang towards Santri City, namely:

1) Periodic plan;

- Short-term plan, which is to conduct a study of the discourse of the city of students and establish a pilot project. (This stage has been implemented by making Rawamerta District a pilot project from the City of Santri).

- Medium-term plan, which is to develop the Santri City zoning in other areas outside Rawamerta after an assessment of the success rate of the previous pilot project.

- Long-term plan, namely the distribution of the City of Santri throughout the Karawang regency by not eliminating local cultural identity and discriminating against non-santri groups.

2) Principles;

In organizing and realizing Karawang Kota Santri, basic principles need to be emphasized in order to avoid disorientation from social values that must be maintained. The principles include:

- Program description, that the branding of Karawang as the City of Santri does not necessarily erase the identity or other characters that have been formed in Karawang, such as Paddy City, Industrial City, Pangkal Perjuangan City, Cross-Religious and Cultural City, and so on. So that the determination of Karawang as the City of Santri must also be accompanied by strengthening other sectors as an affirmation of the identity of this very potential Karawang uniqueness.

- The purpose, namely the intention of the Karawang City of Santri which leads towards the improvement and equitable distribution of Islamic education as well as efforts to build quality human resources and build an ideal civilization for all Karawang people.

- Clarity is the target, so that the objectives of Karawang Kota Santri can be achieved effectively and efficiently. The main targets of the realization of the Karawang City of Santri are the Pondok Pesantrens and formal madrasa education, namely Madrasah Ibtidaiyah (MI), Madrasan Tsanawiyah (MTs), Madrasah Aliyah (MA) to Islamic Higher Education (PTAI) and non-formal madrasa education namely Raudlatul Athfal (RA), Al-Qur'an Education Park (TPQ) and Diniyah Takmiliyah Awaliyah (DTA). 


\section{3) Organizing;}

In the planning stage, various things needed before the program implementation must be prepared. Among those that must be prepared are the methods, tools and techniques and strategies that will be used to help facilitate the realization of Karawang towards the City of Santri.

b. Implementation

The implementation phase is a form of actualization of all the plans that have been prepared. In this stage, which must be considered are:

1) Environmental management

2) Organizing activities

c. Evaluation

The evaluation phase is carried out as a foundation for evaluating, improving and developing a program. This evaluation phase consists of:

1) Techniques used

2) The scope or scope of the evaluation carried out

3) The evaluation process must be carried out periodically, intensively, thoroughly and continuously

4) Management of the results obtained from the evaluation process

5) Follow up after the evaluation is done thoroughly

\section{Conclusion}

From the discussion above, the author can conclude several points as follows:

1. Karawang City of Santri is a discourse issued by the Karawang Regency Ministry of Religion to improve the quality of society by instilling Islamic values in daily life. By implementing and instilling the values of Islamic teachings, a prosperous, safe, comfortable, orderly, harmonious and beautiful society. The concept offered by the Karawang Regency Ministry of Religion is actually a form of practice of the values of Islamic civilization contained in the Quran, namely Surat al-Baqarah verse 126. The verse describes a community life that is in a safe and secure country, and abundant fortune and its inhabitants who believe.

2. In realizing the Karawang City of Santri, it is necessary to take the right steps for successful implementation and maximum achievement of goals. In its realization, Karawang Kota Santri will be applied in zoning, but in the future there will be efforts to align in the field of Islamic education by optimizing the potential of Islamic educational institutions both formally and non-formally. The steps to be taken are:

a. The initial step of the realization of this program is to make Rawamerta a pilot project.

b. After Rawamerta is made as a pilot project, efforts will be made to have religious nuances.

c. Must also be supported by making policies that favor the pesantren and madrasa.

3. In an effort to realize Karawang Kota Santri, an implementation and management standard must be made that can be used as procedural and technical guidelines formulated from various related sources. The standard is considered important as a benchmark as well as guidelines for achieving success in achieving goals, namely the realization of Karawang into the City of Santri. The implementation standards are as planning, implementation and evaluation. 


\section{References}

[1] Wahyudi, M. Z. Mempercepat Pembangunan, Mengejar Ketertinggalan. Kompas, p. 14. (2016, August 27).

[2] Fakta Karawang. Bupati Akui IPM Karawang Masih Rendah. Fakta Karawang, p. 1. (2018, March 19).

[3] Santoso, J. [Menyiasati] Kota tanpa Warga. Jakarta: KPG dan Centropolis. p. 105. (2006).

[4] Poerwadarminta, W. J. S. Kamus Umum Bahasa Indonesia. Jakarta: Balai Pustaka. p. 618. (2007).

[5] Tarigan, R. Perencanaan Pembangunan Wilayah. Jakarta: Bumi Aksara. p. 108. (2004).

[6] Asrohah, H. Pesantren di Jawa; Asal Usul Perkembangan Pelembagaan. Jakarta: Departemen Agama RI. p. 17. (2002).

[7] Sumpeno, A. Pembelajaran Pesantren; Suatu Kajian Komparatif. Jakarta: Departemen Agama RI. p. 4. (2002).

[8] Dhofier, Z. Tradisi Pesantren; Studi Pandangan Hidup Kyai dan Visinya mengenai Masa Depan Indonesia. Jakarta: LP3ES. p. 41. (2011).

[9] Suparta, M., \& Haedari, A. Manajemen Pondok Pesantren. Jakarta: Diva Pustaka. p. 90. (2005).

[10] Nata, A. Sejarah Pertumbuhan dan Perkembangan Lembaga-Lembaga Pendidikan Islam di Indonesia. Jakarta: PT. Grasindo. p. 112. (2001).

[11] Dhofier, Z. Tradisi Pesantren; Studi Pandangan Hidup Kyai dan Visinya mengenai Masa Depan Indonesia. Jakarta: LP3ES. p. 79. (2011).

[12] A., Doni K. Pendidik Karakter di Zaman Keblinger. Jakarta: Grasindo. p. 1. (2018).

[13] An-Nahlawi, A. Usul al-Tarbiyah al-Islamiyah wa Asalibuha, Trans. Herry Noer Ali. Bandung: Diponegoro. p. 30. (1996).

[14] An-Nahlawi, A. Usul al-Tarbiyah al-Islamiyah wa Asalibuha, Trans. Herry Noer Ali. Bandung: Diponegoro. p. 30-31. (1996).

[15] Langgulung, H. Pendidikan Islam dalam Abad 21. Jakarta: Pustaka Al Husna Baru. p. 169. (2002).

[16] Sauri, S. Pendidikan Karakter dalam Perspektif Islam. Bandung: Rizqi Press. p. 29. (2013).

[17] Majalah Patriot News. Kecamatan Rawamerta Menuju Kota Santri. Majalah Patriot News Edition 42/Tahun VI/25 Februari s.d. 25 Maret 2016, p. 21. (2016).

[18] Karni, A. S. Etos Studi Kaum Santri; Wajah Baru Pendidikan Islam. Bandung: Mizan. p. $409 \&$ 411. (2009). 